\title{
Washington International Renewable Energy Conference (WIREC) 2008 Pledges: Methodology and Assumptions Summary
}

Technical Report NREL/TP-670-43919

August 2008

Bill Babiuch, Daniel E. Bilello, Shannon C. Cowlin, Margaret Mann, and Alison Wise

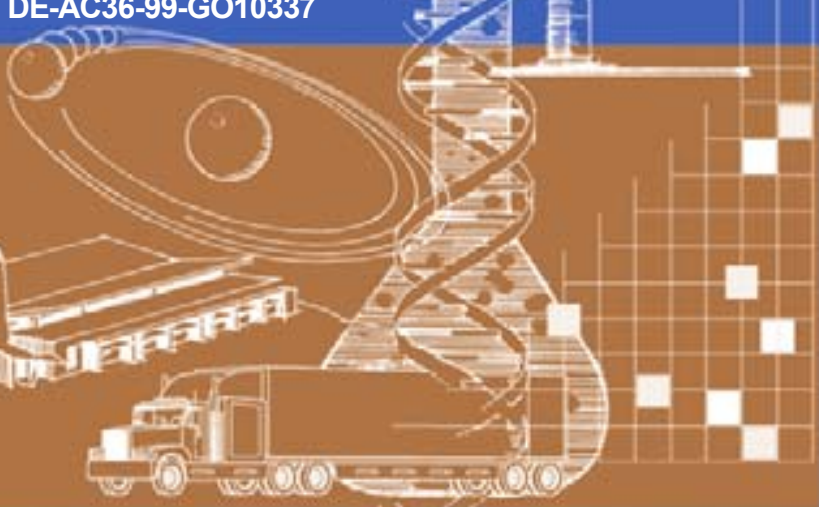




\section{Washington International Renewable Energy Conference (WIREC) 2008 Pledges: Methodology and Assumptions Summary}

Bill Babiuch, Daniel E. Bilello, Shannon C. Cowlin, Margaret Mann, and Alison Wise

Prepared under Task No. SAO7.5109

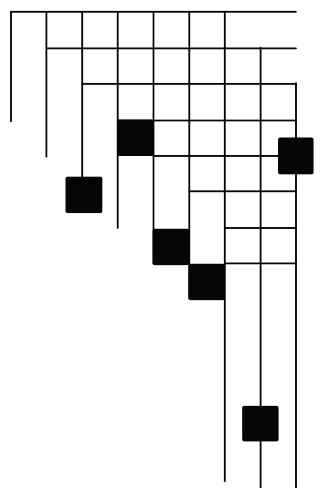




\section{NOTICE}

This report was prepared as an account of work sponsored by an agency of the United States government. Neither the United States government nor any agency thereof, nor any of their employees, makes any warranty, express or implied, or assumes any legal liability or responsibility for the accuracy, completeness, or usefulness of any information, apparatus, product, or process disclosed, or represents that its use would not infringe privately owned rights. Reference herein to any specific commercial product, process, or service by trade name, trademark, manufacturer, or otherwise does not necessarily constitute or imply its endorsement, recommendation, or favoring by the United States government or any agency thereof. The views and opinions of authors expressed herein do not necessarily state or reflect those of the United States government or any agency thereof.

Available electronically at http://www.osti.gov/bridge

Available for a processing fee to U.S. Department of Energy and its contractors, in paper, from:

U.S. Department of Energy

Office of Scientific and Technical Information

P.O. Box 62

Oak Ridge, TN 37831-0062

phone: 865.576 .8401

fax: 865.576 .5728

email: mailto:reports@adonis.osti.gov

Available for sale to the public, in paper, from:

U.S. Department of Commerce

National Technical Information Service

5285 Port Royal Road

Springfield, VA 22161

phone: 800.553 .6847

fax: 703.605.6900

email: orders@ntis.fedworld.gov

online ordering: http://www.ntis.gov/ordering.htm 


\section{Introduction}

The 2008 Washington International Renewable Energy Conference (WIREC) was held in Washington, D.C., from March 4-6, 2008, and involved nearly 9,000 people from 125 countries. The event brought together worldwide leaders in renewable energy (RE) from governments, international organizations, nongovernmental organizations, and the private sector to discuss the role that renewables can play in alleviating poverty, growing economies, and passing on a healthy planet to future generations. The conference concluded with more than 140 pledges from governments, international organizations, and private-sector representatives to advance the uptake of renewable energy (see Table 1 at the end of this report).

The U.S. government authorized the National Renewable Energy Laboratory (NREL) to estimate the carbon dioxide $\left(\mathrm{CO}_{2}\right)$ savings that would result from the pledges made at the 2008 conference. This report describes the methodology and assumptions used by NREL in quantifying the potential $\mathrm{CO}_{2}$ reductions derived from those pledges.

As a first step in this process, analysts reviewed and placed each WIREC pledge in one of two categories (Tier 1 or Tier 2). Tier 1 pledges were characterized as pledges that included specific metrics (e.g., " $x$ " number of megawatts (MW) of renewable energy technology installed; or " $y$ " percentage of renewable energy in total energy mix) where a specific greenhouse gas (GHG) impact could be derived from the pledge. Tier 2 pledges were defined as pledges that will enable broader RE deployment, but did not include specific quantifiable elements that would allow for a specific GHG impact to be derived. Examples include research and development (R\&D), resource assessments, grants, loans, and project financing. Because this distinction was not entirely clear in all cases, NREL asked contributors to review their pledges and provide any additional information or detail if they viewed a Tier 2 pledge as more appropriate for Tier 1 classification.

To facilitate easier review and consistency across Tier 1 pledges, NREL developed four standard templates to evaluate common pledges. These included pledge targets measured by: 1) Installed RE Capacity; 2) Total Primary Energy Supply provided by renewables; 3) Total Primary Energy Consumption met by renewables; and, 4) Alternative Fuels produced. The templates were populated by the pledge information and other assumed factors outlined in the sections below. For those pledges that did not logically fit in one of these categories, analysts carried spreadsheet-based calculations using the same methodology outlined below, but a standard template was not used.

Unless specifically noted in the pledge text, the baseline year for energy and emissions growth was 2005. This start date allowed for consistency across pledges and facilitated the use of a common International Energy Agency (IEA) database for 2005 energy use.

The analysis used incremental GHG reductions from 2009 through 2030 for all pledges, with the assumption that measurable GHG impacts from pledges made at the WIREC conference in the spring of 2008 would begin in 2009 . Analysts selected 2030 as the end date, which would provide a reasonable time horizon to demonstrate the benefit of cumulative reductions during that period. 
The source text for all pledges was taken from the Renewable Energy Policy Network for the 21st Century (REN21) Web site, ${ }^{1}$ which included the written definition and assumptions for each pledge provided by the pledge maker. In cases where pledges included multiple commitments such as both an electricity and a fuels component - the elements of the pledge were assessed individually.

\section{General Approach}

Most regions impacted by WIREC pledges had some level of renewable energy penetration at the time of the conference in 2008. This analysis assumed that only renewable energy use from 2009-2030 could be attributed to pledges made at WIREC. To estimate the additional benefits from the pledges, analysts subtracted the total renewable energy contribution in 2008 from the renewable energy contributions in 2009-2030.

The general equation used to estimate GHG emission reductions resulting from each nonfuels WIREC pledge is shown in Equation 1.

$\left(\mathrm{CO}_{2} \text { emission reductions }\right)_{i}=\left[(\mathrm{RE} \text { use })_{i}-(\mathrm{RE} \text { use })_{2008}\right] *\left(\Delta \mathrm{CO}_{2} \mathrm{EF}\right)_{\text {base year }}$

In Equation 1, $i=$ year $>2008$ and $\leq 2030 ; R E$ use $=$ RE electricity, energy consumption, energy production, or fuel use depending on the sector(s) targeted by the pledge; and $\triangle C_{2} E F$ is the change in emission factor from the traditional energy mix to the renewable energy mix $\left(\mathrm{CO}_{2} \mathrm{EF}\right.$ for traditional energy mix $-\mathrm{CO}_{2} \mathrm{EF}$ for the renewable energy use). The GHG emissions reductions attributable to the pledge were estimated by summing the annual reductions occurring in 2009-2030.

\section{Emission Factors}

The GHG emission reduction estimates from nonfuel pledges assumed that GHG emissions from RE are zero. In addition, analysts assumed that each unit of electricity reduced through energy efficiency (EE) measures offset an equivalent unit generated at the average national emission factor. Although renewable technologies such as wind and solar have GHG emissions associated with manufacturing and transportation and, to a lesser degree, operation and maintenance, emission factors levelized over the lifetime of these units will be orders of magnitude less than those from fossil fuels. This should not substantially impact the emission-reduction estimates that apply to these technologies. This is not necessarily the case for bio-based renewable energy production, whose GHG emission factors can vary widely and depend greatly on feedstock type and cultivation processes. This simplification will add some degree of uncertainty to the GHG emission-reduction results.

The assumption that GHG emissions from renewables is zero means that the "change in emission" factor used in Equation 1 is equal to the emission factor for the traditional energy mix. Analysts based the emission factors on whether the pledge applied to total electricity generation,

\footnotetext{
${ }^{1}$ http://www.ren21.net/wiap/wirec.asp
} 
energy consumption, or energy production. The emission intensity for each of these metrics was available by country for 2005 . For this analysis, the emission factors from 2005 were applied for calculations of GHG reductions in all subsequent years to 2030 .

Emission factors for the electricity sector, which analysts obtained from the IEA, ${ }^{2}$ were reported in units of grams $(\mathrm{g}) \mathrm{CO}_{2}$ per kilowatt hour $(\mathrm{kWh})$. NREL obtained emission factors for energy production from the IEA Web site, which reports the total primary energy supply (TPES) $\mathrm{CO}_{2}$ EF on the Indicators page for each country in units of tons $\mathrm{CO}_{2}$ per ton of oil equivalent (toe). ${ }^{3}$ Analysts obtained emission factors for energy consumption from data available on the Energy Information Administration (EIA) Web site. The EIA reports total primary energy consumption (TPEC) in quadrillion British thermal units (BTU) and $\mathrm{CO}_{2}$ emissions from consumption of fossil fuels on its country-level Energy Profiles. ${ }^{4}$ Analysts used these values to compute the emission factor for pledge-impact estimates using TPEC.

\section{Baseline Total and Renewable Energy Use and Growth Factors}

To estimate the impact of pledges to increase renewable energy to a percentage of supply or consumption in a given year, analysts first estimated what the total supply and consumption would be during the analysis period. Base-year electricity generation values were obtained from the IEA Electricity/Heat pages for each country; the total production values on these pages were used as the base-year electricity values. When a pledge referred to total production, the TPES values from the IEA Indicators were used as the base-year values. For pledges referencing energy consumption, the total primary energy consumption values on the EIA country profile were used as the base-year values.

NREL obtained the growth rates applied to these base-year values from the IEA World Energy Outlook, ${ }^{5}$ which reports consumption demand growth in percentage per year, based on status in the Organization for Economic Cooperation and Development (OECD) and continent. This analysis assumed constant growth rates from the base year to 2030 (the analysis period). Because the coarse aggregation of growth rates and assumption of constant growth added error to the analysis, reviewers were encouraged to provide more accurate, country-specific information where available.

When baseline renewable energy contribution was provided by the pledging agency, those values were used in the analysis. For pledges that did not include baseline renewable energy data, values were collected from the IEA Web site country pages. When baseline electricity use was required to compute the pledge impact, the gross electricity generation in 2005 from all renewable sources was summed to get total gigawatt hours (GWh) in that base year. For pledges targeting total production, analysts converted the gross electricity generation, gross heat production, and domestic supply reported on the IEA renewables pages to common units and

\footnotetext{
2 International Energy Agency Data Services. (2007). "CO2 Emissions from Fuel Combustion (2007 Edition).”

${ }^{3} \mathrm{http}: / / \mathrm{www}$. iea.org/Textbase/country/index.asp

${ }^{4} \mathrm{http}: / /$ tonto.eia.doe.gov/country/index.cfm

${ }^{5}$ IEA, World Energy Outlook. (2006). Paris, France. November 2006. Pp. $492-527$
} 
summed them for all renewable sources; these were then used to compute the percentage contribution to TPES. For pledges targeting consumption, analysts summed the gross electricity generation, gross heat production, and total final consumption values from the IEA renewables pages for use as the base-year renewable contribution to TPEC.

This analysis assumed that renewables experienced linear growth between the base year and the target year, and that the renewable contribution to the energy mix remained constant after the target year until 2030. For example, if a country had $0 \%$ renewable electricity at the time of WIREC (2008) and stated a target of $10 \%$ renewable electricity by 2012 , the percent renewable contribution would grow by $2.5 \%$ each year until 2012. The total GWh corresponding to $10 \%$ of the total electricity production in 2012 is assumed to be an ongoing contribution for all years 2013-2030.

\section{Units and Conversions}

The reporting units of pledge impacts depended on the target sector of the pledges, with electricity-sector estimates based on $\mathrm{kWh}$, and TPES and TPEC based on toe. When reported values did not correspond to these numbers, analysts used the IEA online unit converter. ${ }^{6}$

The final results for the $\mathrm{CO}_{2}$ avoided in the pledge's target year, and cumulatively for 20092030, are reported in million metric tons of $\mathrm{CO}_{2}$.

\section{Fuel Consumption Calculations}

If data for fuel consumption was not included in the specific pledge, analysts obtained information from the IEA database for 2005. Using the IEA Web site country pages, fuel data was obtained from the "Oil" link in the transport section; data for motor gasoline was obtained from the column titled "Motor Gasoline" from the same IEA country page; and data for petrodiesel was obtained from the column titled "Gas/Diesel."

All conversion factors were based on information from the bioenergy section of Oak Ridge National Laboratory's Web site. ${ }^{7}$ Using this database and IEA data from the sources noted above, the following conversions were used:

Motor Gasoline = 1,356 L/tonne.

Petrodiesel $=0.84 \mathrm{~g} / \mathrm{ml}$ (converts to $1,190 \mathrm{~L} /$ tonne $)$.

"Motor Gasoline" IEA data was multiplied by the motor gasoline conversion factor $(1,356$ L/tonne) to get liters of motor gasoline consumption.

The "Gas/Diesel" IEA data was multiplied by the petrodiesel conversion factor (1,190 L/tonne) to get liters of gas/diesel consumption.

Motor gasoline consumption (in liters) and the gas/diesel consumption (in liters) were summed to get the final number used in the calculation spreadsheet.

\footnotetext{
${ }^{6}$ http://www.iea.org/textbase/stats/unit.asp

${ }^{7}$ http://bioenergy.ornl.gov/main.aspx
} 
Renewable fuels were assumed for the purposes of this analysis to be cellulosic ethanol, corn ethanol, and biodiesel. The fuel pledge for each country was assumed to be met with ethanol or biodiesel in the same relative proportion as current use of gasoline and petrodiesel. Ethanol was assumed to be $50 \%$ sugar/starch-based (e.g., corn or sugar cane) and 50\% lignocellulosic. Greenhouse gas emissions savings with this ethanol mix as a replacement for gasoline was estimated to be about $40 \%$. Biodiesel was assumed to reduce greenhouse gas emissions by $50 \%$ from petrodiesel; varying biomass sources and cultivation practices made more precise estimates impractical.

\section{Summary}

The WIREC 2008 pledge process clearly demonstrates that renewable energy will play a key role in the global effort to meet future energy needs and reduce greenhouse gas emissions. While there are still methodological and data challenges in measuring the precise GHG impact of the measures proposed, there is no doubt that many nations are looking at renewable energy technologies as a way to meet a large part of their future energy needs as well as reduce their carbon footprint, particularly in the electricity sector. NREL evaluated 145 WIREC pledges, which have the potential to provide thousands of megawatts of renewable electricity capacity through 2030, and eliminate billions of tons of $\mathrm{CO}_{2}$ that otherwise would have been generated from conventional sources.

The WIREC 2008 pledges represent a diverse number of actors and sectors, illustrating a wide variety of opportunities that exist to accelerate renewable energy markets. In addition, the diversity of these pledges shows that both mandatory and voluntary approaches can complement one another in achieving real and measurable impacts on the ground. In respect to the Tier 2 pledges that were not quantified in this exercise, the likely market impact is also significant. For example, research and development $(R \& D)$ pledges will play a key role in helping meet renewable energy goals without overburdening national economies because the 10 - to 20 -year timeline for most pledge goals will enable renewable energy technical milestones to be met, thereby significantly reducing the commercial costs of these electricity and alternative fuel options. Financial and in-kind pledges also will help reduce the near-term economic burdens of renewable energy options, particularly in developing countries.

Project leaders hope that this methodological exercise and the associated templates will directly assist in the process of evaluating new pledges and tracking progress on existing voluntary commitments. With this goal in mind, all of the calculation spreadsheets, templates, and supporting documents will be maintained on a public database for viewing and updating. 
Table 1. WIREC 2008 Pledges - Estimate of CO2 and Biofuel Impacts if Goals are Met by Target Years

Final Table - August 28, 2008

\begin{tabular}{|c|c|c|c|c|c|c|c|c|c|}
\hline Tier & Lead Entity & Pledge & $\begin{array}{c}\text { Target } \\
\text { Year }\end{array}$ & $\begin{array}{c}\text { Annual } \mathrm{CO} 2 \\
\text { Reduced in } \\
\text { Target Year } \\
\text { (MMT) }\end{array}$ & $\begin{array}{l}\text { Cumulative } \\
\text { CO2 Reduced } \\
2009-2030 \\
\text { (MMT) }\end{array}$ & $\begin{array}{l}\text { Annual Petro } \\
\quad \text { Fuels } \\
\text { Displaced In } \\
\text { Target Year } \\
\text { (million liters) }\end{array}$ & $\begin{array}{c}\text { Cumulative } \\
\text { Petro Fuels } \\
\text { Displaced 2009. } \\
2030 \text { (million } \\
\text { liters) }\end{array}$ & $\begin{array}{c}\text { Annual CO2 } \\
\text { Reduced from } \\
\text { Biofuels Produced } \\
\text { in Target Year } \\
\text { (MMT) }\end{array}$ & \begin{tabular}{|c|} 
Cumulative \\
cO2 Reduced \\
from Biofuels \\
Produced from \\
2008-2030 \\
(MMT)
\end{tabular} \\
\hline 1 & Australia / Government of Australia & $20 \%$ target for renewables in Australia's electricity supply by 2020 & 2020 & 29.80 & 483.87 & & & & \\
\hline 1 & Rwanda / Government of Rwanda & $90 \%$ of renewable energy in electricity production by 2012 & 2012 & 0.03 & 0.56 & & & & \\
\hline 1 & American Jewish Committee, USA ${ }^{1}$ & A U.S. Human Rights NGO Going Green & & & & & & & \\
\hline 1 & Kenya / Ministry of Energy & $\begin{array}{l}\text { Accelerate renewable energy growth through Formulating and } \\
\text { Instituting a policy on renewable energy development in the next two }\end{array}$ & 2020 & 0.36 & 5.95 & & & & \\
\hline 2 & USA / Department of Commerce & Access of renewable energy technologies in China and India & & & & & & & \\
\hline 1 & Pakistan / Planning and Development & $\frac{\text { Achieve } 10 \% \text { share of renewable energy in the national energy mix by }}{2012}$ & 2012 & 6.25 & 127.65 & & & & \\
\hline 2 & Equity International, Inc., USA & Achieving $100 \%$ RPS by all 50 U.S. states & & & & & & & \\
\hline 1 & Spain / Ministry of Industry, Tourism and Tra & $\begin{array}{l}\text { Action Plan to increase use of renewables to at least } 12 \% \text { by } 2010 \\
\text { and increase energy efficiency }\end{array}$ & 2010 & 13.64 & 293.15 & 805 & 17,303 & 1.13 & 24.28 \\
\hline 2 & USA / Department of Transportation & $\begin{array}{l}\text { Alternative fuel vehicle testing and research on required biofuels } \\
\text { infrastructure. }\end{array}$ & & & & & & & \\
\hline 1 & USA / Department of State & APP grants add renewable power in India & 2015 & 0.18 & 3.45 & & & & \\
\hline 2 & $\begin{array}{l}\text { Global Network on Energy for Sustainable } \\
\text { Development }\end{array}$ & $\begin{array}{l}\text { Assessment of priority options for biofuels strategy for poverty } \\
\text { alleviation and achieving the important MDGs in selected regions and }\end{array}$ & & & & & & & \\
\hline 2 & USA / Climate Institute & $\begin{array}{l}\text { Assist a dozen small island states in developing and implementing } \\
\text { sustainable energy plans }\end{array}$ & & & & & & & \\
\hline 1 & Bangkok Metropolitan Administration, Thailar & $\begin{array}{l}\text { Bangkok's program on initiatives to alleviate the effects of climate } \\
\text { change }\end{array}$ & 2012 & 7.30 & 149.72 & & & & \\
\hline 1 & France / Government of France & Beyond $20 \%$ of RE in the final energy consumption by 2020 & 2020 & 60.12 & 981.81 & 3,787 & 62,309 & 5.22 & 85.96 \\
\hline 2 & USA / Trade and Development Agency & Biomass power generation feasibility study in Namibia & & & & & & & \\
\hline 2 & USA / Department of Energy & Biomass products market cost targets through 2012 & & & & & & & \\
\hline 2 & Germany / Government of Germany & $\begin{array}{l}\text { Boosting energy research and demonstration in innovative fields of } \\
\text { renewable energy }\end{array}$ & & & & & & & \\
\hline 2 & Germany; Spain; Slovenia / Governments & Boosting international cooperation on feed-in systems & & & & & & & \\
\hline 2 & EarthAction International, USA & $\begin{array}{l}\text { Bring 'Feed In' legislation to state and federal governments in the US,- } \\
\text { convince } 10 \text { States within two years }\end{array}$ & & & & & & & \\
\hline 2 & Solar Generation International & $\begin{array}{l}\text { Campaign geared towards public awareness and real solutions on } \\
\text { climate change through renewable energy and energy efficiency }\end{array}$ & & & & & & & \\
\hline 2 & Philippines / Miriam Colleage & $\begin{array}{l}\text { Campaign t i increase public education and awareness of renewable } \\
\text { energy and the environment }\end{array}$ & & & & & & & \\
\hline 2 & $\begin{array}{l}\text { Indira Gandhi Institute of Development } \\
\text { Research, India }\end{array}$ & $\begin{array}{l}\text { Capacitit building for creating access to clean, affordable and reliable } \\
\text { energy services for the rural households and urban poor households }\end{array}$ & & & & & & & \\
\hline 1 & City of Bellingham, WA, USA ${ }^{1}$ & City of Bellingham commits to $100 \%$ green power & & & & & & & \\
\hline 2 & $\begin{array}{l}\text { Global Urban Development and Rockefeller } \\
\text { Brothers Fund, USA }\end{array}$ & $\begin{array}{l}\text { Climate Prosperity Project to increase public awareness about the } \\
\text { opportunities of engaging in climate protection }\end{array}$ & & & & & & & \\
\hline 1 & College of the Atlantic, USA ${ }^{1}$ & College of the Atlantic $100 \%$ renewable by 2015 & & & & & & & \\
\hline 2 & USA / Department of the Interior & Complete national geothermal resource assessment by end of 2008 & & & & & & & \\
\hline 2 & USA / Department of the Interior & $\begin{array}{l}\text { Complete Regulatory framework for alternative energy development } \\
\text { on the Outer Continental Shelf }\end{array}$ & & & & & & & \\
\hline 2 & European Renewable Energy Council & $\begin{array}{l}\text { Council to facilitate EE's commitment to obtain } 20 \% \text { of energy needs } \\
\text { from renewale energy by } 2020\end{array}$ & & & & & & & \\
\hline 2 & Fundacion Solar, Guatemala & $\begin{array}{l}\text { Create a positive energy fototrint in everyday practices of indigenous } \\
\text { populations through education, social organization and envirionmental }\end{array}$ & & & & & & & \\
\hline 2 & Haiti / Government of Haiti & Creating the proper environment for renewable energy in Haiti & & & & & & & \\
\hline 2 & $\begin{array}{l}\text { International Institute for Sustainable } \\
\text { Development }\end{array}$ & $\begin{array}{l}\text { Creation of ENERGY-L distribution list for international sustainable } \\
\text { energy activities }\end{array}$ & & & & & & & \\
\hline
\end{tabular}




\begin{tabular}{|c|c|c|c|c|c|c|c|c|c|}
\hline Tier & Lead Entity & Pledge & $\begin{array}{l}\text { Target } \\
\text { Year }\end{array}$ & $\begin{array}{c}\text { Annual CO2 } \\
\text { Reduced in } \\
\text { Target Year } \\
\text { (MMT) }\end{array}$ & $\begin{array}{l}\text { Cumulative } \\
\text { CO2 Reduced } \\
2009-2030 \\
\text { (MMT) }\end{array}$ & $\begin{array}{l}\text { Annual Petro } \\
\text { Fuels } \\
\text { Displaced In } \\
\text { Target Year } \\
\text { (million liters) }\end{array}$ & $\begin{array}{c}\text { Cumulative } \\
\text { Petro Fuels } \\
\text { Displaced 2009. } \\
2030 \text { (million } \\
\text { liters) }\end{array}$ & \begin{tabular}{|c|} 
Annual $\mathrm{CO} 2$ \\
Reduced from \\
Biofuels Produced \\
in Target Year \\
(MMT)
\end{tabular} & \begin{tabular}{|c|} 
Cumulative \\
CO2 Reduced \\
from Biofuels \\
Produced from \\
2008-2030 \\
(MMT)
\end{tabular} \\
\hline 2 & $\begin{array}{l}\text { Cemtec, Aalborg University / Northern } \\
\text { Jutland, Denmark }\end{array}$ & $\begin{array}{l}\text { Creation of Hydrogen Valley - Cluster for hydrogen and fuel cell } \\
\text { business }\end{array}$ & & & & & & & \\
\hline 2 & Poland / Ministry of Economy & $\begin{array}{l}\text { Develop and implement national program for agricultural biogas } \\
\text { plants and introduce white certificate mechanism for energy efficiency }\end{array}$ & & & & & & & \\
\hline 2 & $\begin{array}{l}\text { Waitukubuli Ecological Foundation, } \\
\text { Dominica }\end{array}$ & $\begin{array}{l}\text { Develop community wind energy projects in Dominica to cover at } \\
\text { least } 25 \% \text { of the island's energy needs }\end{array}$ & & & & & & & \\
\hline 1 & St. Kitts and Nevis / Government of St. Kitts & Develop various renewable energy technologies and energy efficiency & 2015 & 0.16 & 2.95 & & & & \\
\hline 2 & $\begin{array}{l}\text { Bahamas / Ministry of Public Works and } \\
\text { Transport }\end{array}$ & Developing an energy policy for the Commonwealth of the Bahamas & & & & & & & \\
\hline 2 & $\begin{array}{l}\text { Institute for Research in Sustainable Energy } \\
\text { and Development, Kenya }\end{array}$ & Development of sorghum for food and bioenergy & & & & & & & \\
\hline 1 & The Netherlands / SNV Netherlands Develop & Domestic biogas: Capturing the markets in Asia and Africa & 2012 & 0.52 & 10.74 & & & & \\
\hline 2 & $\begin{array}{l}\text { Ireland / Department of Communications, } \\
\text { Energy and Natural Resources }\end{array}$ & $\begin{array}{l}\text { Domestic grant programme of EUR } 58 \mathrm{~m} \text { for biomass, solar and } \\
\text { geothermal technologies }\end{array}$ & & & & & & & \\
\hline 2 & Switzerland / Government of Switzerland & $\begin{array}{l}\text { Double the interdepartmental platform budget to CHF } 4 \mathrm{~m} \text { in } 2008 \text { - } \\
2010 \text { to promote renewable energy and efficiency in international }\end{array}$ & & & & & & & \\
\hline 2 & Germany / Government of Germany & $\begin{array}{l}\text { Dubbling the special facility for renewable energy and energy } \\
\text { efficiency }\end{array}$ & & & & & & & \\
\hline 2 & International Green Energy Council, USA & $\begin{array}{l}\text { Educating leaders and students worldwide about the benefits of } \\
\text { energy efficiency and renewable energy }\end{array}$ & & & & & & & \\
\hline 2 & USA / Department of the Interior & Efficiency improvements in 58 hydroelectric power plants & & & & & & & \\
\hline 2 & Greenpeace International & $\begin{array}{l}\text { Energy [Rlevolution } 2008 \text { - communicating A Sustainable World } \\
\text { Energy Outlook }\end{array}$ & & & & & & & \\
\hline 2 & $\begin{array}{l}\text { Ireland / Department of Communications, } \\
\text { Energy and Natural Resouces }\end{array}$ & $\begin{array}{l}\text { EUR } 20 \mathrm{~m} \text { research fund to increase energy research capacity in } \\
\text { Ireland }\end{array}$ & & & & & & & \\
\hline 2 & $\begin{array}{l}\text { Ireland / Department of } \\
\text { Communications,Energy and Natural }\end{array}$ & EUR $26 \mathrm{~m}$ for ocean energy research and development & & & & & & & \\
\hline 2 & Germany / Government of Germany & $\begin{array}{l}\text { EUR } 550 \mathrm{~m} \text { to renewable energy and energy efficiency in developing } \\
\text { countries in } 2008\end{array}$ & & & & & & & \\
\hline 1 & Japan / Ministry of Economy, Trade and Indu & $\begin{array}{l}\text { Expanding introduction of renewable energy to } 3 \% \text { of total primary } \\
\text { energy supply by } 2010\end{array}$ & 2010 & 37.37 & 803.52 & & & & \\
\hline 1 & Nicaragua / Ministry of Energy and Mines & $\begin{array}{l}\text { Expanding renewable electricity generation to } 38 \text { percent by } 2011 \text {, } \\
\text { improving regulatory framework for renewable energy investments, }\end{array}$ & 2011 & 0.18 & 3.76 & & & & \\
\hline 1 & Tokyo Metropolitan Government, Japan & Expansion of the Use of Solar Energy & 2016 & 0.75 & 13.89 & & & & \\
\hline 1 & UK / Department for Business, Enterprise anc & $\begin{array}{l}\text { "Expedite offshore wind farm development to contribute to the UK's } \\
\text { target of } 10 \% \text { of electricity generation from renewables by } 2010\end{array}$ & 2020 & 47.43 & 782.67 & & & & \\
\hline 2 & USA / Department of Agriculture & Federal biobased preferred product procurement & & & & & & & \\
\hline 2 & USA / Department of Transportation & $\begin{array}{l}\text { Federal Transit Administration Clean Fuels and Advanced Propulsion } \\
\text { Technologies Program with focus on field testing in public transit. }\end{array}$ & & & & & & & \\
\hline 1 & Germany / Government of Germany & Feed biogas into the natural gas network & 2030 & 22.80 & 248.46 & & & & \\
\hline 2 & $\begin{array}{l}\text { UK / Department for Business, Enterprise } \\
\text { and Regulatory Reform }\end{array}$ & Funding a European marine energy test centre & & & & & & & \\
\hline 2 & $\begin{array}{l}\text { USA A Overseas Private Investment } \\
\text { Corporation }\end{array}$ & Global renewable energy facility to be created in 2008 & & & & & & & \\
\hline 2 & $\begin{array}{l}\text { Baylor Institute for Air SciencesSpirit of } \\
\text { Hispaniola, USA }\end{array}$ & Green airport and International Flight Academy on biofuels & & & & & & & \\
\hline 1 & USA / Environmental Protection Agency & $\begin{array}{l}\text { Green Power Partnership includes } 850 \text { private partners buying } 17 \text { bn } \\
\text { KWh of green power in } 2008\end{array}$ & 2009 & 9.74 & 214.30 & & & & \\
\hline 1 & Cape Verde / Ministry of Economy, Growth a & $\begin{array}{l}\text { Greening Cape Verde: } 50 \% \text { renewables in nationwide power } \\
\text { production by } 2020,100 \% \text { on one island }\end{array}$ & 2020 & 0.02 & 0.27 & & & & \\
\hline 2 & USA / Department of State & Greening United States embassies & & & & & & & \\
\hline 2 & GreenMotion & $\begin{array}{l}\text { Identify at least } 1,000 \text { new ideas, technologies, processes, and } \\
\text { techniques which will help meet the global energy needs in a }\end{array}$ & & & & & & & \\
\hline 1 & Sweden / Ministry of Enterprise, Energy and & $\begin{array}{l}\text { Implement energy policy to reach } 49 \% \text { of renewable energy by } 2020 \\
\text { and long-term sustainability }\end{array}$ & 2020 & 8.51 & 139.11 & & & & \\
\hline 1 & Germany / Government of Germany & $\begin{array}{l}\text { lmplementation of the strategy of the German Government on the use } \\
\text { of offshore wind energy }\end{array}$ & 2030 & 27.52 & 316.42 & & & & \\
\hline 2 & USA / Agency for International Develpment & $\begin{array}{l}\text { Improved access to clean energy services in developing countries } \\
\text { with USD 125m in } 2008\end{array}$ & & & & & & & \\
\hline 1 & Forrester Partners Limited, UK ${ }^{1}$ & $\begin{array}{l}\text { Incentive program to encourage employees of Forrester Partners } \\
\text { Limited to switch to renewable energy }\end{array}$ & & & & & & & \\
\hline
\end{tabular}




\begin{tabular}{|c|c|c|c|c|c|c|c|c|c|}
\hline Tier & Lead Entity & Pledge & $\begin{array}{c}\text { Target } \\
\text { Year }\end{array}$ & $\begin{array}{l}\text { Annual CO2 } \\
\text { Reduced in } \\
\text { Target Year } \\
\text { (MMT) }\end{array}$ & $\begin{array}{l}\text { Cumulative } \\
\text { CO2 Reduced } \\
2009-2030 \\
\text { (MMT) }\end{array}$ & $\begin{array}{l}\text { Annual Petro } \\
\quad \text { Fuels } \\
\text { Displaced In } \\
\text { Target Year } \\
\text { (million liters) }\end{array}$ & $\begin{array}{c}\text { Cumulative } \\
\text { Petro Fuels } \\
\text { Displaced 2009. } \\
2030 \text { (million } \\
\text { liters) }\end{array}$ & $\begin{array}{c}\text { Annual CO2 } \\
\text { Reduced from } \\
\text { Biofuels Produced } \\
\text { in Target Year } \\
\text { (MMT) }\end{array}$ & $\begin{array}{c}\text { Cumulative } \\
\text { CO2 Reduced } \\
\text { from Biofuels } \\
\text { Produced from } \\
\text { 2008-2030 } \\
\text { (MMT) }\end{array}$ \\
\hline 2 & Canada / Government of Canada & Inclusion of renewable energy tax incentives in the 2008 budget & & & & & & & \\
\hline 1 & Brazil / Government of Brazil & $\begin{array}{l}\text { Increase renewable energy and implement Ten-year Plan for Energy } \\
\text { Expansion to match expected } 47 \% \text { increase in installed electric }\end{array}$ & 2025 & 39.66 & 509.97 & & & & \\
\hline 2 & GE Energy Financial Services & Increase renewables investment to USD 6 bn by 2010 & & & & & & & \\
\hline 1 & European Union / Council of the European U & $\begin{array}{l}\text { Increase share of renewable energy to } 20 \% \text { and reduce greenhouse } \\
\text { gas emissions by } 20 \% \text { in the EU by } 2020\end{array}$ & 2020 & $1,028.18$ & $59,116.07$ & & & & \\
\hline 1 & Lithuania / Ministry of Economy & Increase share of renewable energy to at least $20 \%$ by 2025 & 2025 & 2.25 & 30.56 & 239 & 3,317 & 0.32 & 4.49 \\
\hline 1 & Morocco / Ministry of Energy, Mines, Water a & $\frac{\text { Increase the contribution of renewable energy to } 10 \% \text { of national }}{\text { energy balance and } 20 \% \text { in electricity supply by } 2012}$ & 2012 & 2.59 & 52.96 & & & & \\
\hline 1 & Italy / Ministry of Economic Development & Increase the share of renewable energies in the energy mix & 2016 & 3.14 & 61.08 & 769 & 16,529 & 1.01 & 21.70 \\
\hline 1 & Denmark / Ministry of Climate and Energy & Increase use of renewable energy and energy efficiency & 2025 & 10.09 & 147.36 & & & & \\
\hline 1 & Cameroon / Ministry of Energy and Water Re & $\frac{€ \text { Increasing energy supply and energy services for sustainable }}{\text { development via accelerated use of renewable energy }}$ & 2020 & 1.10 & 23.23 & 3,000 & 64,000 & 1.06 & 22.53 \\
\hline 1 & Argentina / Government of Argentina & $\begin{array}{l}\text { Increasing renewable energy to } 8 \% \text { of electricity consumption by } \\
2016,5 \% \text { of fuels by 2011, and promoting rural access to renewable }\end{array}$ & 2016 & 2.70 & 50.75 & 410 & 8,599 & 0.56 & 11.71 \\
\hline 1 & Netherlands / Government of the Netherlands & 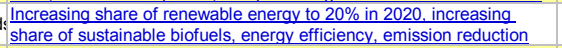 & 2020 & 77.43 & $1,276.86$ & & & & \\
\hline 1 & Volvo Group ${ }^{1}$ & $\begin{array}{l}\text { Increasing the use of renewable energy in production and products, } \\
\text { and increasing energy efficiency }\end{array}$ & & & & & & & \\
\hline 1 & Planet2025 Network & $\begin{array}{l}\text { Integration of sustaianable biofuel crops as renewable energy } \\
\text { component into community based agroforestry efforts }\end{array}$ & 2009 & 0.30 & 6.60 & & & & \\
\hline 1 & Switzerland / Department of the Environment & $\begin{array}{l}\text { Introduction of Action Plan for renewable heat sources to raise share } \\
\text { of renewable energy in TPES from } 16,2 \% \text { to } 24 \% \text { by } 2020\end{array}$ & 2020 & 4.40 & 72.04 & & & & \\
\hline 2 & USA / Trade and Development Agency & $\begin{array}{l}\text { Jatropha biodiesel development feasibility study for possible large- } \\
\text { scale production }\end{array}$ & & & & & & & \\
\hline 2 & USA / Department of the Interior & $\begin{array}{l}\text { Land use planning to increase renewable energy development on } \\
\text { public lands }\end{array}$ & & & & & & & \\
\hline 2 & Canada / Government of Canada & $\begin{array}{l}\text { Latest version of the Government of Canada's (NRCan) RETScreen } \\
\text { Clean Energy Project Analysis Software - officially launched }\end{array}$ & & & & & & & \\
\hline 2 & USA / Department of Treasury & Launch USD 2bn Clean Technology Fund & & & & & & & \\
\hline 1 & Switzerland / Department of the Environment & $\begin{array}{l}\text { Legally based financial mechanism for accelerated market penetration } \\
\text { of renewable electricity to boost generation by } 5.4 \text { TWh by } 2030\end{array}$ & 2030 & 0.14 & 1.61 & & & & \\
\hline 2 & India / City Managers' Association Orissa & Local Government Climate Change Adaptation Programme & & & & & & & \\
\hline 1 & Uganda / Ministry of Energy and Mineral Dev & $\begin{array}{l}\text { Making modern renewable energy a substantial part of Uganda's } \\
\text { national energy consumption, up from } 4 \% \text { to } 61 \% \%\end{array}$ & 2017 & 1.06 & 18.88 & & & & \\
\hline 2 & Energy Efficiency Centre, Georgia & $\begin{array}{l}\text { Nation wide campaign for the promotion of renewable energy and } \\
\text { energy efficiency }\end{array}$ & & & & & & & \\
\hline 1 & Paraguay / Ministry of Industry and Commerc & $\frac{\text { National Biofuels Development Plan to expand biofuels from } 5 \% \text { to }}{50 \% \text { by } 2013}$ & 0 & 0.90 & 17.87 & 621 & 12,368 & 0.90 & 17.87 \\
\hline 1 & Madagascar / Ministry of Energy and Mines & National policies to achieve $54 \%$ renewable energy share by 2020 & 2020 & 1.39 & 22.45 & & & & \\
\hline 2 & Afghanistan / Ministry of Energy and Water & $\begin{array}{l}\text { National policy and public awareness campaign on renewable energy } \\
\text { use in Afghanistan and reduction of air pollution in Kabul }\end{array}$ & & & & & & & \\
\hline 1 & $\begin{array}{l}\text { Indonesia / Ministry of Energy and Mineral } \\
\text { Resources }\end{array}$ & $\begin{array}{l}\text { New national energy policy to optimize the national primary energy } \\
\text { mix by increasing share of renewable energy to } 15 \% \text { in } 2025 \\
\end{array}$ & 2025 & 300.26 & $4,032.22$ & & & & \\
\hline 1 & My Organic Market, LLC, USA ${ }^{1}$ & Offset $100 \%$ of energy usage by purchasing wind energy & & & & & & & \\
\hline 1 & Juniata College, USA & Offsetting $75 \%$ of electricity consumption through wind energy credits & 2012 & 0.00 & 0.05 & & & & \\
\hline 2 & USA / Environmental Protection Agency & $\begin{array}{l}\text { Partnership for Clean Indoor Air to reduce exposure of } 750,000 \text { people } \\
\text { in developing countries by } 2009\end{array}$ & & & & & & & \\
\hline 2 & Grameen Shakti, Bangladesh & $\begin{array}{l}\text { Policy advocacy for formulating and declaring a national renewable } \\
\text { energy policy for Bangladesh }\end{array}$ & & & & & & & \\
\hline 1 & Latvia / Ministry of the Environment & Programme for the development of production and use of biogas & 2030 & 0.02 & 0.29 & & & & \\
\hline 2 & USA / U.S. Trade and Development Agency & $\begin{array}{l}\text { Project preparation assistance, investment analysis, project definition, } \\
\text { sector develoomment. and trade capacity building to accelerate }\end{array}$ & & & & & & & \\
\hline 1 & $\begin{array}{l}\text { Azerbaijan / Ministry of Ecology and Natural } \\
\text { Resources }\end{array}$ & $\begin{array}{l}\text { Promote and increase utilisation of wind and solar energy in the } \\
\text { country }\end{array}$ & 2012 & 0.03 & 0.51 & & & & \\
\hline 2 & Norway / Ministry of Foreign Affairs & Promote and support renewable energy in developing countries & & & & & & & \\
\hline
\end{tabular}




\begin{tabular}{|c|c|c|c|c|c|c|c|c|c|}
\hline Tier & Lead Entity & Pledge & $\begin{array}{c}\text { Target } \\
\text { Year }\end{array}$ & $\begin{array}{l}\text { Annual CO2 } \\
\text { Reduced in } \\
\text { Target Year } \\
\text { (MMT) }\end{array}$ & $\begin{array}{l}\text { Cumulative } \\
\text { CO2 Reduced } \\
2009-2030 \\
\text { (MMT) }\end{array}$ & \begin{tabular}{l|} 
Annual Petro \\
Fuels \\
Displaced In \\
Target Year \\
(million liters)
\end{tabular} & $\begin{array}{c}\text { Cumulative } \\
\text { Petro Fuels } \\
\text { Displaced 2009. } \\
2030 \text { (million } \\
\text { liters) }\end{array}$ & $\begin{array}{c}\text { Annual CO2 } \\
\text { Reduced from } \\
\text { Biofuels Produced } \\
\text { in Target Year } \\
\text { (MMT) }\end{array}$ & \begin{tabular}{|c|} 
Cumulative \\
CO2 Reduced \\
from Biofuels \\
Produced from \\
2008-2030 \\
(MMT)
\end{tabular} \\
\hline 2 & Partnership International, Inc, USA & $\begin{array}{l}\text { Promote financinq, development, implementation, and dissemination } \\
\text { of best-practice model to help expand solar and wind power in African }\end{array}$ & & & & & & & \\
\hline 2 & Biomass Coordinating Council, USA & $\begin{array}{l}\text { Promoting collaboration and information sharing on biomass through } \\
\text { WIKI platform }\end{array}$ & & & & & & & \\
\hline 1 & $\begin{array}{l}\text { Jordan / Ministry of Energy and Mineral } \\
\text { Resources }\end{array}$ & $\begin{array}{l}\text { Promoting the utilisation of renewable energy sources to share } 10 \% \text { in } \\
\text { the primary energy by the vear } 2020\end{array}$ & 2020 & 2.25 & 35.75 & & & & \\
\hline 2 & Switzerland / Department of Finance & Promotion of biofuels & & & & & & & \\
\hline 2 & Shri Jagdamba Samiti, India & $\begin{array}{l}\text { Promotion of pico hydro power unit in Garhwal Himalayas for agro- } \\
\text { processing - revival programme of traditional water mills }\end{array}$ & & & & & & & \\
\hline 2 & $\begin{array}{l}\text { World Experience for Georgia (Foundation), } \\
\text { Georgia }\end{array}$ & $\begin{array}{l}\text { Promotion of renewable energy in Georgia through policy } \\
\text { development, increased awareness and regional cooperation }\end{array}$ & & & & & & & \\
\hline 1 & Tunisia / National Agency for Energy Conser & $\begin{array}{l}\text { Promotion of renewable energy to reach } 10 \% \text { in national energy } \\
\text { demand by } 2011 \text { and reduction of total demand }\end{array}$ & 2011 & 7.12 & 151.53 & & & & \\
\hline 2 & Canada / Government of Canada & $\begin{array}{l}\text { Provide CAD } 4 \text { bn in funding to the e ecoENERGY Initiatives in support } \\
\text { of renewable energy and energy efficiency in Canada }\end{array}$ & & & & & & & \\
\hline 2 & $\begin{array}{l}\text { UK / Department for Environment, Food and } \\
\text { Rural Affairs }\end{array}$ & $\begin{array}{l}\text { Provide financiai l support for commercial scale anaerobic digestion } \\
\text { demonstration lants }\end{array}$ & & & & & & & \\
\hline 2 & $\begin{array}{l}\text { Tanzania Traditional Energy Development } \\
\text { and Environment Organization }\end{array}$ & $\begin{array}{l}\text { Providing energy access to at least } 1 \text { million people through use of } \\
\text { renewable energy in order to reduce poverty }\end{array}$ & & & & & & & \\
\hline 2 & $\begin{array}{l}\text { ADEME, EDF, Fondation Energies pour le } \\
\text { Monde, GERES FRANCE }\end{array}$ & $\begin{array}{l}\text { Providing energy services through renewable energy technologies to } \\
1.5 \mathrm{~m} \text { people in off-grid rural and peri-urban areas }\end{array}$ & & & & & & & \\
\hline 2 & NatureWorks, LLC, USA & $\begin{array}{l}\text { Purchasing green power to offset electricity used in manufacturing } \\
\text { process }\end{array}$ & & & & & & & \\
\hline 1 & $\begin{array}{l}\text { New Zealand / Ministry of Economic } \\
\text { Development }\end{array}$ & Reach $90 \%$ renewable electricity target by 2025 & 2025 & 4.94 & 67.00 & & & & \\
\hline 1 & Norway / Ministry of Petroleum and Energy & $\begin{array}{l}\text { Reach combined target for renewable energy and energy efficiency: } \\
30 \text { TWh increased annual production from } 2001 \text { to } 2016\end{array}$ & 2016 & 0.10 & 1.78 & & & & \\
\hline 1 & USA / Environmental Protection Agency & $\begin{array}{l}\text { Recovery of landfill methane to reduce greenhouse gas emissions } \\
\text { and generate renewable energy from } 560 \text { landfills by } 2012\end{array}$ & 2012 & 24.00 & 492.00 & & & & \\
\hline 1 & $\begin{array}{l}\text { Jamaica / Ministry of Energy, Mining \& } \\
\text { Telecommunication Petroleum Corporation }\end{array}$ & $\begin{array}{l}\text { Reduce dependence on imported fossil fuels through the development } \\
\text { of indigenous renewable energy resources to } 10 \% \text { of the electricity }\end{array}$ & 2020 & 0.95 & 15.02 & & & & \\
\hline 1 & Town of Warrenton, Virginia, USA & $\begin{array}{l}\text { Reduce the carbon footprint of Warrenton by } 25 \% \text { by } 2012 \text { primarily } \\
\text { through a waste to energy plant }\end{array}$ & 2012 & 0.08 & 1.69 & & & & \\
\hline 2 & $\begin{array}{l}\text { UK / Department for Business, Enterprise } \\
\text { and Regulatory Reform }\end{array}$ & Reform of financial support to renewable electricity generators & & & & & & & \\
\hline 1 & Germany / Government of Germany & $\begin{array}{l}\text { Renewable Energies Heat Act to help increase share of renewable } \\
\text { energies in heat provision to } 14 \% \text { by } 2020\end{array}$ & 2020 & 5.77 & 94.14 & & & & \\
\hline 1 & $\begin{array}{l}\text { Turkey / Ministry of Energy and Natural } \\
\text { Sources }\end{array}$ & Renewable energy and energy efficiency targets and regulation & 433 & 30.16 & 479.01 & 3,529 & 46,157 & 4.83 & 63.17 \\
\hline 1 & USA / Department of Defense & $\begin{array}{l}\text { Renewable energy production and procurement to reach } 25 \% \text { of the } \\
\text { Department's facility electrical consumption by } 2025\end{array}$ & 2025 & 1.69 & 23.66 & & & & \\
\hline 1 & Germany / Government of Germany & $\begin{array}{l}\text { Renewable Energy Sources Act } \mathrm{ACEG} \text { t thelp raise share of } \\
\text { renewable electricity to } 25-30 \% \text { by 2020 }\end{array}$ & 2020 & 69.05 & $1,118.95$ & & & & \\
\hline 1 & USA / Department of Agriculture & $\begin{array}{l}\text { Renewable energy systems and energy efficiency improvements } \\
\text { program with loan guarantees and grants }\end{array}$ & 2013 & 0.39 & 7.82 & & & & \\
\hline 1 & USA / Department of Energy & $\begin{array}{l}\text { Renewable energy use requirements for federal facilities and vehicle } \\
\text { fleets through } 2015\end{array}$ & 2015 & 2.41 & 51.60 & 56 & 1,082 & 0.05 & 1.04 \\
\hline 1 & USA / Environmental Protection Agency & $\begin{array}{l}\text { Renewable fuel standard of } 36 \text { bn gallons by } 2022 \text {, with sub- } \\
\text { requirement of } 21 \text { bn gallons of advanced biofuels by } 2022\end{array}$ & 2022 & 115.37 & $1,572.80$ & 94,019 & $1,555,629$ & 115.37 & $1,572.80$ \\
\hline 2 & Firestar Engineering, LLC, USA & $\begin{array}{l}\text { Research into non-carbon-based fuels and low temperature energy } \\
\text { conversion processes }\end{array}$ & & & & & & & \\
\hline 2 & $\begin{array}{l}\text { University of Hawaii-Hilo, College of } \\
\text { Agriculture, Forestry and Natural Resource }\end{array}$ & $\begin{array}{l}\text { Research project tor the growing of palm oil in Hawaii on abandoned } \\
\text { sugar cane lands }\end{array}$ & & & & & & & \\
\hline 1 & France / Electricite De France & Rural electrification in South Africa with photovoltaic kits & 2028 & 0.00 & 0.03 & & & & \\
\hline 1 & Egypt / Ministry of Electricity and Energy & $\begin{array}{l}\text { Satisfying } 20 \% \text { of the Egyptian generated electricity by renewable } \\
\text { energies, mainly wind \& hydro, by } 2020\end{array}$ & 2020 & 15.66 & 258.36 & & & & \\
\hline 2 & Prokaushali Sangsad Limited, Bangladesh & $\begin{array}{l}\text { Scaling up RE technology application and adaptation to the impact of } \\
\text { climate change }\end{array}$ & & & & & & & \\
\hline 1 & USA / Environmental Protection Agency & $\begin{array}{l}\text { SmartWay Grow \& Go partnership with freight industry to increase use } \\
\text { of renewable fuels }\end{array}$ & 2012 & 9.99 & 207.89 & 10,409 & 216,502 & 9.99 & 207.89 \\
\hline 2 & USA / Department of Energy & Solar America Initiative & & & & & & & \\
\hline 2 & $\begin{array}{l}\text { USA / National Aeronautics and Space } \\
\text { Administration }\end{array}$ & $\begin{array}{l}\text { Solar resource assessment using earth observations with emphasis on } \\
\text { products for the developing world }\end{array}$ & & & & & & & \\
\hline 1 & USA, State Governments & State Renewable Portfolio Standards (RPS) & 2020 & 181.24 & $2,990.46$ & & & & \\
\hline
\end{tabular}




\begin{tabular}{|c|c|c|c|c|c|c|c|c|c|}
\hline Tier & Lead Entity & Pledge & $\begin{array}{l}\text { Target } \\
\text { Year }\end{array}$ & $\begin{array}{l}\text { Annual CO2 } \\
\text { Reduced in } \\
\text { Target Year } \\
\text { (MMT) }\end{array}$ & $\begin{array}{l}\text { Cumulative } \\
\text { CO2 Reduced } \\
2009-2030 \\
\text { (MMT) }\end{array}$ & $\begin{array}{c}\text { Annual Petro } \\
\text { Fuels } \\
\text { Displaced In } \\
\text { Target Year } \\
\text { (million liters) }\end{array}$ & $\begin{array}{c}\text { Cumulative } \\
\text { Petro Fuels } \\
\text { Displaced 2009. } \\
2030 \text { (million } \\
\text { liters) }\end{array}$ & $\begin{array}{c}\text { Annual } \mathrm{CO2} \\
\text { Reduced from } \\
\text { Biofuels Produced } \\
\text { in Target Year } \\
\text { (MMT) }\end{array}$ & \begin{tabular}{|c} 
Cumulative \\
CO2 Reduced \\
from Biofuels \\
Produced from \\
2008-2030 \\
(MMT)
\end{tabular} \\
\hline 2 & Norway / Ministry of Petroleum and Energy & Step up energy research and development policy & & & & & & & \\
\hline 2 & Tanzania / Ministry of Energy and Minerals & $\begin{array}{l}\text { Strengthen the legal, regulatory and institutional framework to support } \\
\text { the development of a sustainable biofuels industry }\end{array}$ & & & & & & & \\
\hline 2 & USA / Export-Import Bank & $\begin{array}{l}\text { Supporting increased renewable energy exports with lending } \\
\text { enhancements }\end{array}$ & & & & & & & \\
\hline 2 & Remineralize the Earth, Inc. (NGO), USA & $\begin{array}{l}\text { The potential of remineralization with rock mineral fines to transform } \\
\text { biofuel production and sezuester carbon }\end{array}$ & & & & & & & \\
\hline 2 & $\begin{array}{l}\text { UK / Department for Environment, Food and } \\
\text { Rural Affairs }\end{array}$ & $\begin{array}{l}\text { UK commitment to fund REEEP, the Renewable Energy and Energy } \\
\text { Efficiecny Parthership, for } 3 \text { years, with GBP } 2.5 \mathrm{~m} \text { available for }\end{array}$ & & & & & & & \\
\hline 1 & Japan / Ministry of Economy, Trade and Indu & $\begin{array}{l}\text { Usage target of } 16 \mathrm{bn} \mathrm{kWh} \mathrm{by} 2014 \text { based on the Renewable Portfolio } \\
\text { Standard law }\end{array}$ & 2014 & 6.86 & 133.85 & & & & \\
\hline 2 & USA / Department of Energy & $\begin{array}{l}\text { USD 10bn Loan guarantee program for renewable and energy } \\
\text { efficiency }\end{array}$ & & & & & & & \\
\hline 1 & Mauritania / Ministry of Hydraulics, Energy ar & Ur Using wind power for sea water desalination & 2010 & 0.02 & 0.51 & & & & \\
\hline 2 & USA / Department of Energy & $\begin{array}{l}\text { Wind Electricity Market Cost Targets for land-based and offshore } \\
\text { systems }\end{array}$ & & & & & & & \\
\hline 2 & USA / Department of Agriculture & Woody biomass grants to turn forest residue into marketable products & & & & & & & \\
\hline 2 & Romanian Energy Policy Association & Workshop for dissemination of WIREC 2008 & & & & & & & \\
\hline 2 & World Bank Group & $\begin{array}{l}\text { World Bank Group Strategic Framework for Climate Change and } \\
\text { Development }\end{array}$ & & & & & & & \\
\hline
\end{tabular}

Notes 1: Not calculated because of lacking baseline data 


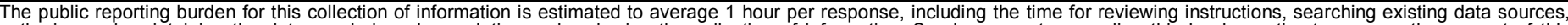

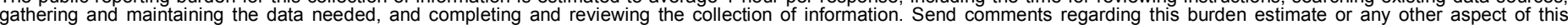

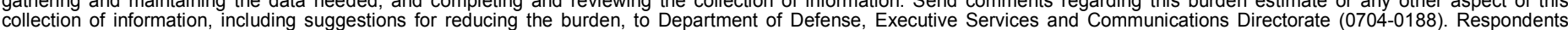

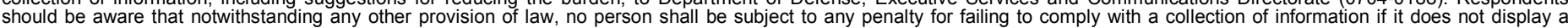

chould be aware that notwithstandin.

PLEASE DO NOT RETURN YOUR FORM TO THE ABOVE ORGANIZATION.
1. REPORT DATE (DD-MM-YYYY) August 2008
4. TITLE AND SUBTITLE
Washington International Renewable Energy Conference (WIREC)
2008 Pledges: Methodology and Assumptions Summary

3. DATES COVERED (From - To)

5a. CONTRACT NUMBER

DE-AC36-99-GO10337

5b. GRANT NUMBER

5c. PROGRAM ELEMENT NUMBER

5d. PROJECT NUMBER

NREL/TP-670-43919

5e. TASK NUMBER

SA07.5109

5f. WORK UNIT NUMBER
7. PERFORMING ORGANIZATION NAME(S) AND ADDRESS(ES)

National Renewable Energy Laboratory

1617 Cole Blvd.

Golden, CO 80401-3393

9. SPONSORING/MONITORING AGENCY NAME(S) AND ADDRESS(ES)
8. PERFORMING ORGANIZATION REPORT NUMBER

NREL/TP-670-43919

10. SPONSOR/MONITOR'S ACRONYM(S) NREL

11. SPONSORING/MONITORING AGENCY REPORT NUMBER

\section{DISTRIBUTION AVAILABILITY STATEMENT}

National Technical Information Service

U.S. Department of Commerce

5285 Port Royal Road

Springfield, VA 22161

\section{SUPPLEMENTARY NOTES}

\section{ABSTRACT (Maximum 200 Words)}

The 2008 Washington International Renewable Energy Conference (WIREC) was held in Washington, D.C., from March 4-6, 2008, and involved nearly 9,000 people from 125 countries. The event brought together worldwide leaders in renewable energy (RE) from governments, international organizations, nongovernmental organizations, and the private sector to discuss the role that renewables can play in alleviating poverty, growing economies, and passing on a healthy planet to future generations. The conference concluded with more than 140 governments, international organizations, and private-sector representatives pledging to advance the uptake of renewable energy. The U.S. government authorized the National Renewable Energy Laboratory (NREL) to estimate the carbon dioxide (CO2) savings that would result from the pledges made at the 2008 conference. This report describes the methodology and assumptions used by NREL in quantifying the potential CO2 reductions derived from those pledges.

\section{SUBJECT TERMS}

Washington International Renewable Energy Conference; WIREC; greenhouse gas emissions; carbon dioxide; CO2; pledges; Shannon C. Cowlin; Bill Babiuch; Daniel E. Bilello; Margaret Mann; Alison Wise

\begin{tabular}{|c|c|c|c|c|}
\hline \multicolumn{3}{|c|}{ 16. SECURITY CLASSIFICATION OF: } & \multirow{2}{*}{$\begin{array}{l}\text { 17. LIMITATION } \\
\text { OF ABSTRACT } \\
\text { UL }\end{array}$} & \multirow{2}{*}{$\begin{array}{l}\text { 18. NUMBER } \\
\text { OF PAGES }\end{array}$} \\
\hline $\begin{array}{l}\text { a. REPORT } \\
\text { Unclassified }\end{array}$ & $\begin{array}{l}\text { b. ABSTRACT } \\
\text { Unclassified }\end{array}$ & $\begin{array}{l}\text { c. THIS PAGE } \\
\text { Unclassified }\end{array}$ & & \\
\hline
\end{tabular}
19a. NAME OF RESPONSIBLE PERSON 